Ф. 3. Канунова

Томск

\title{
ИССЛЕДОВАНИЕ И ПЕРЕВОД НОВОГО ЗАВЕТА \\ В НРАВСТВЕННО-ЭСТЕТИЧЕСКИХ \\ ИСКАНИЯХ В. А. ЖУКОВСКОГО
}

В архиве Пушкинского Дома сохранилась первая копия с подлинной рукописи перевода В. А. Жуковского «Новый Завет Господа нашего Иисуса Христа», сделанная в 1885 году в Санкт-Петербурге и подаренная $\begin{array}{lll}\text { М. Соловьеву } & \text { П. В. Жуковским в } 1890 \text { году }^{2} \text {. Этому }\end{array}$ переводу предшествовало

\footnotetext{
(C) Канунова Ф. 3., 2008

${ }^{1}$ Соловьев Михаил Петрович (1842-1901) - административный деятель; в 1864 году окончил курс в Московском университете по юридическому факультету, долгое время служил при канцелярии военного министра, в 1896 году назначен членом совета главного управления по делам печати и до 1900 года исправлял должности начальника этого управления.

${ }^{2}$ Архив Пушкинского Дома, р. 1, оп. 9, ед. 54. На последней странице поэт написал: «Дарю эту рукопись на Новый год и в день рождения сыну моему Павлу, которому нынче исполнился один год. Да будет над ним благодать Господа Бога и нашего Спасителя Иисуса Христа». Пометы в рукописи определяют начало и конец работы. После Евангелия от Матфея помечено: «кончено 19/31 дек. 1844, Франкфурт-на-Майне»; после Евангелия от Иоанна: «начато в 1844, в июне месяце, во Фр.-на-Майне, — кончено в 1845 г. (апр.<ель $>10 / 22$, в среду, на страстной неделе. Господи, в руце Твои предаю дух мой». После Деяний - «начало 19 апр. (1 мая) конч.<ено> мая 15 (27) 1845». После Откровения «1 янв. 1846 г. Фр.на-Майне». На последнем листе сделаны следующие записи, проясняющие историю данной копии: «К. П. Победоносцев, сняв копию с этой копии, имеет в виду напечатать перевод для немногих». Ниже другим почерком: «Рукопись эта приобретена мною у Л. Ф. Мелина за 100 руб. 1907 года 25 мая. Мусвиц-Шадурский».
} 
Еще ниже красным карандашом другим почерком: «Рукопись эта приобретена мною в 1910 году у Л. Ф. Мелина за 125 р. Жевержеев». Первый и единственный раз перевод Жуковского был опубликован в Берлине в 1895 году: Новый Завет Господа нашего Иисуса Христа: Пер. В. А. Жуковского. Берлин, 1895.

\section{8}

многолетнее, можно сказать, пожизненное изучение Священного Писания. Следы вдохновенного проникновения в евангельские тексты вошли во многие и многие произведения Жуковского. Множество его помет таят в себе принадлежащие ему экземпляры Нового Завета ${ }^{3}$. Рукописные архивные материалы поэта, характер самого перевода Нового Завета, выполненного Жуковским, позволяют поставить вопрос о значении этого перевода и многолетней подготовки к нему в эстетике и творчестве Жуковского.

Размышления о религии и Боге пронизывают собой с самого начала 1800-х годов письма Жуковского к наиболее близким ему людям - А. И. и И. П. Тургеневым. Так, 31 августа 1805 года Жуковский пишет А. И. Тургеневу:

Хочу обратить внимание на религию. Она нужнее и действительнее простой, умственной философии. Но только хочу: испытаю и увижу ${ }^{4}$.

Этими же мыслями пестрят дневники Жуковского:

Какие вопросы я должен делать себе каждый день? О христианской морали в сравнении с философической: основать последнюю на первой (1806).

Как известно ${ }^{5}$, уже с самого начала своего творческого пути Жуковский, глубоко проникая в коренные проблемы философии человека, осмысляя огромную литературу о сути антропологии (Руссо, Юм, Гердер, Гольбах, Гельвеций), серьезно задумывается о соотношении 
философии и религии. Это был важнейший вопрос не только для Жуковского, но и для декабристов -

\footnotetext{
${ }^{3}$ Несколько изданий Нового Завета из личного собрания Жуковского хранятся сегодня в Научной библиотеке Томского государственного университета. Они буквально испещрены множеством помет, свидетельствующих об удивительной активности читателя.

${ }^{4}$ Письма В. А. Жуковского А. И. Тургеневу. М., 1895. С. 7.

${ }^{5}$ См.: Библиотека В. А. Жуковского в Томске. Ч. $1-3$. Томск, $1978-1988$.
}

Бестужева-Марлинского ${ }^{6}$, Кюхельбекера, Раевского, Батенькова ${ }^{7}$, отдававших дань немецкой идеалистической философии. Утверждение высокой сущности человека (человек - микрокосм), философия самопознания и лежащая в ее основе идея развития - все это, как известно, ценили у Шеллинга русские романтики 1820 начала 1830 -х годов. Но думается, что уже в 1830 -е годы, и особенно в 1840-е годы, у передовых людей, ищущих высокого реального дела, было свое отношение к немецкой классической философии, переживавшей уже тогда глубокий кризис. Все отчетливее проявлялась ее главная слабость - неспособность органически соединить реальное, действительное и идеальное.

В русской культуре чуть ли ни с начала XIX века, особенно к концу 1820-1830-х годов, зреет острая потребность в идее, интегрирующей и восстанавливающей органическую целостность бытия. Рационалистическая отвлеченность немецкой философии многими понималась как ведущая в тупик. Именно так многие прогрессивные деятели 1840-1850-х годов понимали материализм (и атеизм) Фейербаха, который Н. Бердяев не без основания назовет «Немезидой гегельянства». «Вся новейшая философия, - говорит 
он, - явно обнаружила свое роковое бессилие познать бытие, соединить с бытием познающего субъекта» ${ }^{8}$. Жуковский все более утверждается в преимуществе религии над философией. Он призывает А. И. Тургенева «бросить Шеллинга и читать Библию» (письмо от 6 марта 1849 года. С. 295). В это же время в записной книжке он размышляет:

Нам, не видевшим глазами Христа, он представляется в Святом Писании; в Новом Завете Он Сам, в Древнем Завете события, предвозвещающие Его пришествие.

Чуть ниже в этой же записной книжке поэт пишет о Библии как о «произведении человеческом» 9 .

1830-1840-е годы занимают особое место в религиозно-нравственных и эстетических исканиях Жуковского. В этот период Жуковский совершенно откровенно осуждает немецкую философию, ее рационализм и материализм. Выходом

\footnotetext{
${ }^{6}$ См.: Канунова Ф. 3. А. А. Бестужев-Марлинский и его Кавказские повести // А. А. Бестужев-Марлинский. Кавказские повести. СПб., 1995 (сер. «Литературные памятники»).

${ }^{7}$ Она же. Г. С. Батеньков и В. А. Жуковский // Ежеквартальник русской филологии и культуры. 1996. Т. 2. № 3. С. 94-106.

${ }^{8}$ Бердяев Н. А. Философия свободы. М., 1989. С. 17.

${ }^{9}$ Жуковский В. А. Мысли и замечания // Наше наследие. 1995. № 33. C. 57.

150

из кризиса представлялась религия, этот «глубинный источник питания». Приход к религии потому был выходом из кризиса, что, во-первых, это означало поворот к реальному бытию, органически связанный с корнями народной культуры и мифологии; во-вторых, это новый источник духовного проникновения в человека, его строения себя, и, в-третьих, это грандиозный синтез
} 
духа и бытия, важнейшее условие решения назревших проблем времени. Все это влекло к религии в 1830-1840е годы поздних декабристов, отказавшихся от односторонности общественно-политического ригоризма.

Жуковский приходит к религии раньше декабристов. Уже с самого начала 1800 -х годов религия для поэта это основа нравственной философии. Она антропологична и глубоко универсальна. Еще в 1803 году в письме И. П. Тургеневу в связи со смертью Ан. Тургенева Жуковский размышляет о Боге как о «безграничном пространстве, в котором существуют и сосредоточиваются все ограниченные пространства» ${ }^{10}$. Здесь же близкие раннеромантическому мистическому переживанию мира мысли о «всемирной душе, объемлющей все своей беспредельностью», и о душе человеческой как «ее духовном атоме».

Составляя часть необъятного целого, мы будем чувствовать и наслаждаться только в отношении к сему целому, и я понимаю, что это наслаждение будет чище и выше ${ }^{11}$.

К 1805-1806 годам относится первое обращение Жуковского к Библии. Это перевод поэтического переложения Ж.-Ж. Руссо легенды о Левите Ефраимском и его наложнице; повесть «Левит Ефраимский» должна была войти в «Избранные сочинения» французского писателя, которые Жуковский задумал издать в собственном переводе ${ }^{12}$.

В середине 1810-х годов большой интерес к Библии у Жуковского связан не только с его творчеством, но и с личной жизнью, с его любовью к Маше Протасовой и с надеждой на счастливую гармоничную жизнь с ней, большую роль в которой должна была, по убеждению поэта, сыграть религия; проникновение в Священное Писание - залог счастливой 
${ }^{10}$ Письма В. А. Жуковского А. И. Тургеневу. С. 9.

${ }^{11}$ Там же.

${ }^{12}$ См. об этом специальное исследование И. А. Айзиковой в кн.: Канунова Ф. 3., Айзикова И. А. Нравственно-эстетические искания русского романтизма и религия (1820-1840-е гг.). Новосибирск, 2001. C. $43-53$.

жизни, по Жуковскому. В своих планах на семейное счастье он пишет:

Маше читать места из Священного Писания... Священное писание - моя исповедь... Красоты Библии. Занятия вместе: Священное Писание. Чтение духовных писателей ${ }^{13}$.

Настойчиво рекомендуя Маше читать Библию, Жуковский просит ее сделать «книжку, в которую записывать лучшее из Священного Писания и духовных писателей» ${ }^{14}$. Первое упоминание о намерении перевести Библию находим в письме Маше (между 15-26 сент. 1814 года) ${ }^{16}$.

К началу 1820-х годов Жуковский буквально погружается в изучение Библии, настойчиво готовясь, по всей видимости, к переводу Нового Завета. Об этом свидетельствуют не исследованные до сих пор его пометы на экземплярах Священного Писания из его библиотеки. Личная библиотека В. А. Жуковского, хранящаяся в значительной своей части в Научной библиотеке Томского государственного университета, содержит многочисленные книги о христианстве, об истории церкви и несколько изданий Священного Писания ${ }^{16}$. Среди них базельское издание Ветхого и Нового Завета 1821 года и парижское издание Нового Завета 1838 года. Эти книги испещрены пометами Жуковского ${ }^{17}$. Интересен составленный Жуковским свод использованных им при чтении помет, которые находим на верхнем форзаце базельского издания Библии: 
- факт истории без выписки

I- факт историч. <еский> с выпискою

- факт. Выписка текста?

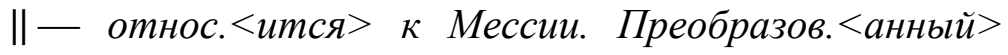
факт

Выписка текста

$+\|$ - пророчество. Относит. $<$ яя $>\kappa$ Мессии

Данный свод помет Жуковского свидетельствует об интересующих его аспектах чтения. Прежде всего его волнует история священного народа. Жуковский стремится собрать фактический материал, отраженный в Библии, и делает соответствующие выписки. Наряду с этим важнейшим

\footnotetext{
${ }_{13}^{13}$ Дневники В. А. Жуковского. СПб., 1903. С. 45-47.

${ }^{14}$ Там же.

${ }^{15}$ Веселовский $A . H . \quad$ В. А. Жуковский: Поэзия чувства и «сердечного воображения». СПб., 1994. С. 168.

${ }^{16}$ См.: Библиотека В. А. Жуковского. Описание. Томск, 1981.

${ }^{17}$ Пометы Жуковского на базельском и парижском изданиях Нового Завета см.: Канунова Ф. З., Айзикова И. А. Указ. соч. С. 209259.

152

для него в библейском тексте является образ Мессии и все, что к нему относится.

Чтение базельского издания Нового Завета 1821 года можно достаточно точно датировать, так как одну из групп помет составляют даты, проставленные последовательно в начале глав или отдельных стихов. Исходя из этой датировки, Евангелие от Матфея Жуковский читал с 16 февраля до 14 апреля, Евангелие от Марка - с 15 апреля до 8 августа, Евангелие от Луки - с 9 августа до 25 октября и Евангелие от Иоанна - с 26 октября до 22 ноября 1844 года, Деяния Святых Апостолов - с 23 ноября до 4 марта 1845 года. Судя по
} 
второй датировке, в период с 22 марта по 11 апреля 1846 года Жуковский перечитывал отдельные места во всех Евангелиях. Это были гл. 21-28 в Евангелии от Матфея, 11-16 в Евангелии от Марка, 19-24 в Евангелии от Луки и 12, 17 в Евангелии от Иоанна. Во всех Евангелиях были перечитаны главы о входе Господнем в Иерусалим и о последовавших событиях до распятия и воскресения Иисуса Христа.

Чтение Жуковского, его датировка и надписи напоминают форму дневника. Например, на полях гл. 27 в Евангелии от Матфея, кроме даты, находим сведения о сыне: «Paul a commence a marcher aujourd'hui». Или в гл. 19 Евангелия от Луки: «Болезнь в течение недели», в гл. 16 Евангелия от Иоанна: «Саша с нами». Все это детали семейной жизни, свидетельствующие о близости чтения Жуковским Евангелия к его домашней жизни. Чтение Евангелия как бы слилось с важнейшими событиями жизни поэта.

Очень тщательно работал Жуковский над парижским изданием Нового Завета. Поэт оставил пометы в Евангелиях от Матфея, Марка, Иоанна и в 9 первых главах Евангелия от Луки, а также в отдельных главах Послания апостола Павла к римлянам, 1-го и 2-го Послания к коринфянам, Послания к ефесянам, к филиппийцам, к колоссянам, в 1-м Послании к фессалониникийцам, в 1-м и 2-м Посланиях к Тимофею, в Послании к евреям, в 1-м Послании Петра и в 1-м Послании Иоанна. Пометы представляют собой подчеркивания, в тексте и отчеркивания на полях. На нижнем форзаце книги поэт пытается в очередной раз выстроить генеалогию Иисуса Христа. Анализ помет Жуковского в Новом Завете позволяет сделать вывод о двух важнейших для него проблемах, определившихся в процессе изучения этой священной книги. Это проблема Мессии и тесно связанная с ней проблема нравственного 
восхождения личности. Остановимся на этом специально. Как показывают дневники, письма и творчество, Жуковский придает первостепенное значение центральной, по его убеждению, идее Евангелия - идее вочеловечивания Абсолюта в образе Иисуса Христа. Уже в раннем стихотворении «Библия» (перевод стихотворения поэта-классициста Л. Фонтана «Les Livres Saints», которое было задумано автором как пролог к переложению библейской Книги Иова, так и неосуществленному) Священное Писание предстает источником многочисленных тем и образов ${ }^{18}$. Заканчивается стихотворение образом «младенца-Бога», «Мессии в пеленах». Сама идея Мессии, посредника между Богом и людьми, носителя высшей истины на Земле, спасителя, осмысливается Жуковским как центр христианской религиозной системы.

«Явление Христа есть вочеловечивание Бога, вхождение его в нашу жизнь», - утверждает А. Мень ${ }^{19}$. На этой мысли постоянно сосредоточивается Жуковский. Вместе с Христом, по его убеждению, в мир приходит новое восприятие жизни и человека, в основе которого утверждение пути нравственного и духовного жизнестроительства как важнейшей цели существования на земле. «До Иисуса Христа, - скажет Жуковский в дневнике 1828 года, - человек возвышался мыслию к Богу и в мире незнакомом и чуждом искал законов для обитаемого им нравственного мира. В Спасителе Божество явилось Земле, и отвлеченные суеверные понятия обратились в ясное, смиренное убеждение сердца» $^{20}$. Это очень значительное признание поэта в пик его зрелого творчества. Именно Христос своей жизнью, проповедью, смертью определил нравственный статус земного человека, начертал путь его жизнестроения. Эти 
важнейшие для Жуковского убеждения выражены в его пометах на личном экземпляре Нового Завета из его библиотеки.

Наиболее обширное из канонических - Евангелие от Матфея, отличающееся членением материала по предметному признаку, то есть размещением речевых мест и их расцвечиваний чудесными деяниями, привлекает пристальное

\footnotetext{
${ }^{18}$ См. комментарий Н. В. Серебренникова к стихотворению в кн.: Жуковский В. А. Полн. собр. соч. и писем. Т. 1. М., 1999. С. 684-688.

${ }^{19}$ Мень А. В поисках подлинного Христа // Культура и духовное возрождение. М., 1992. С. 68 . На особой важности земной человеческой жизни Христа делает акцент А. Мень и в своей книге «Сын человеческий».

${ }^{20}$ Жуковский В. А. Из дневников 1827-1840-х гг. // Наше наследие. 1994. № 32. С. 47.
}

\section{4}

внимание Жуковского. Оно направлено на те речи Сына Божия, которые посвящены спасению человечества. Жуковский тщательно выделяет те великие мысли Мессии, которые направлены на нравственное восхождение человека. Так, он выделяет отчеркиванием на полях или подчеркиванием в тексте, например, следующие слова Мессии:

Не хлебом одним будет жить человек, но всяким словом, исходящим из уст Божиих (Гл. 4. Ст. 4).

Пойдите, научитесь, что значит: «Милости хочу, а не жертвы?»- ибо Я пришел призвать не праведников, но грешников к покаянию (Гл. 9. Ст. 13).

С огромным вниманием вчитывается Жуковский в Нагорную проповедь, что очевидно совпадает и с характером его перевода Нового Завета. Так, он подчеркивает следующие заповеди: 
Блаженны кроткие, ибо они наследуют землю (Гл. 5. Ст. 5). Блаженны милостивые, ибо они помилованы будут ${ }^{21}$ (Ст. 7).

И далее, вдумываясь в текст Евангелия от Матфея, Жуковский тщательно выделяет заповеди Иисуса Христа:

Иисус сказал ему: «Возлюби Господа Бога твоего всем сердцем твоим, и всею душою твоею, и всем разумением твоим» (Гл. 22. Ст. 37).

Сия есть первая и наибольшая заповедь (Ст. 38).

Уже в предшествующем чтению перечне своих помет Жуковский выделяет (в двух случаях!) мессианскую роль Христа. Таковы, например, пометы «\|- относ. $<$ ится $>$ к Мессии. Преобразов.<анный> факт. Выписка текста» и $«+\|-$ пророчество. Относит. $<$ ся $>$ к Мессии». Это подтверждается в процессе чтения Жуковского, скажется и на его переводе Нового Завета. Он тщательно подчеркивает мессианскую, пророческую роль Христа:

И, приблизившись, Иисус сказал им: «дана Мне всякая власть на небе и на земле (Гл. 28. Ст. 18).

Итак, идите, научите все народы, крестя их во имя Отца и Сына и Святого Духа (Ст. 19).

В этом же плане обращают на себя внимание и другие пометы Жуковского: 1, 9; 6, 13; 11, 28; 11, 30; 16, 24; 18, $20 ; 21,9 ; 23,12$ и т. д., в Евангелии от Марка - 2, 28; 8, $34 ; 11,25$.

\footnotetext{
${ }^{21}$ Все эти подчеркивания встречаем и в парижском издании 1838 года, см. «Приложение» (Канунова Ф. З., Айзикова И. А. Указ. соч.).
}

Отчеркивает и подчеркивает Жуковский и многие афористически-притчевые изречения. Это, прежде всего, все отмеченные поэтом заповеди из Нагорной проповеди: 
...итак, будьте мудры, как змии, и просты, как голуби (Гл. 10. Ст. 16).

Так будут последние первыми и первые последними; ибо много званных, а мало избранных (Гл. 20. Ст. 16) ${ }^{22}$.

Многие отчеркивания Жуковского выделяют слова и формы молитвы, характеризуя значение для поэта молитвенного слова:

А молясь, не говорите лишнего, как язычники, ибо они думают, что в многословии своем будут услышаны (Гл. 6. Ст. 7).

Молитесь же так:

Отче наш, сущий на небесах! Да святится имя Твое (Ст. 9). Да придет Царствие Твое; да будет воля Твоя и на земле, как на небе (Ст. 10).

Или в Послании к колоссянам:

Будьте постоянны в молитве, бодрствуя в ней с благодарением (Гл. 4. Ст. 2).

Земная жизнь Христа, его смерть глубоко интересовали Жуковского. Это со всей очевидностью следует из восприятия русским поэтом Священного Писания и из его творчества 1820-1830-х годов. В 1818 году Жуковский переводит кантату К. Рамлера «Смерть Иисуса» ${ }^{23}$. Кантата Рамлера буквально соткана из евангельских реминисценций. В переводе Жуковского стремление высветить главные мотивы кантаты немецкого поэта: мотив жертвенной смерти Христа, «обремененного грехами преступными земли», трагедию предательства, мотив прощения и покаяния. Однако главный пафос Рамлера, основная нота его произведения - страдание, одиночество, покинутость Христа. Жуковский в своем переводе делает акцент на спасительной, жертвенной смерти Иисуса во имя «величия жизни». Он отталкивается от мелодраматизма 
немецкого поэта, уходит от всяческого нагнетания внешних примет страдания Христа, углубляет представление о высоких мотивах его гибели. Передавая достаточно точно главные мотивы кантаты Рамлера, в своем переводе Жуковский делает акцент на жизненной силе подвига Христа. Своеобразным

\footnotetext{
${ }^{22}$ См. также пометы в: 7, 1; 9, 13; 10, 28; 11, 6; 15, 11; 17, 20; 22, 39 и др.

${ }^{23}$ РНБ, ф. 286, оп. 2, № 24.

\section{6}

ключом к переводу Жуковского может служить его запись в дневнике от 16 февраля 1821 года о восприятии жизни и смерти Христа Иоанном, «учеником и товарищем Спасителя»:
}

Он смотрит на небо как на обитель удалившегося друга и не стремится туда, ибо земная жизнь оставлена ему в наследство, как благо... И слышит отовсюду: Спаситель твой жив ${ }^{24}$.

О том, что земная жизнь, проповедь и смерть Христа служат духовному воскресению человека, Жуковский говорит много раз.

В своем переводе евангельского сюжета «Смерть Иисуса» Жуковский идет от Евангелия от Матфея, от Луки, и особенно от Иоанна, дающего большой простор для усиления драматической и психологической глубины сцены. Евангелие от Иоанна, по признанию авторитетных исследований, - наиболее философичное и символичное из всех Евангелий. Здесь настойчиво подчеркивается мировой, вселенский смысл жизни Христа. Так, например, Жуковский-читатель, переводчик, поэт усиливает напряженное внимание к мотиву отношений Пилата и Христа, к возвращению сомнений в душе Пилата, а затем к убежденности прокуратора Иудеи в невинности Христа и к приговору Сына Бога к смерти. 
Тогда вышел Иисус в терновом венце и багрянице. И сказал им Пилат: Се человек!

В своей «лебединой песне», в «Агасфере», Жуковский воспроизводит слова Иоаннова Евангелия:

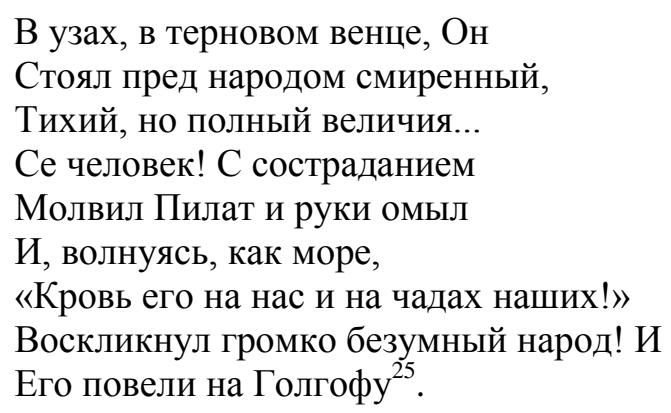

Это явилось символико-мифологической заставкой к «Агасферу» (см. ниже). Жуковский пророчески осознавал важность этого сюжета для русской истории и русского человека. Не случайно сюжет «Христос и Пилат», в центре

\footnotetext{
${ }^{24}$ Дневники В. А. Жуковского. С. 105.

${ }^{25}$ Жуковский В. А. Полн. собр. соч.: В 12 т. СПб., 1902. Т. 8. С. 96.
}

которого ситуация измены, предательства и суда, пройдет через произведения многих русских писателей (Л. Толстой, А. Чехов, М. Булгаков, Ю. Домбровский, Ч. Айтматов). Обратимся к творчеству Л. Н. Толстого.

Большое значение для понимания глубинной идеи романа «Анна Каренина» имеет эпизод посещения Анной и Вронским за границей мастерской художника Михайлова, картина которого на сюжет «Увещевание Пилатом» содержит поистине символический смысл. Фабульная сторона самой картины Михайлова - 27-я гл. Евангелия от Матфея - об увещевании Пилатом. Мудрый римский прокуратор Понтий Пилат пытается 
спасти невинного, но ему это не удается. В 27-й гл. читаем:

Пилат, видя, что ничто не помогает, но смятение увеличивается, взял воды и умыл руки перед народом, и сказал: «Невинен я в крови праведника сего, смотрите все».

В этих словах очерчена фабульная сторона картины Михайлова. Момент досады Пилата на себя и спокойное лицо Иисуса Христа отражены в картине Михайлова. Как воспринимают картину Михайлова герои Толстого?

В отличие от Вронского, отметившего прекрасную технику художника, Анна обратила внимание на центр картины - изображение Христа, оно более всего взволновало героиню Толстого. Она разглядела в выражении лица Христа сострадание. «Видно, - говорит она, - Христу жалко Пилата». Пилат осуждает и убивает того, кто был олицетворением духовной жизни и воплощением любви.

В картине Михайлова главное - ситуация измены, предательства и суда. Анне не случайно жалко Пилата, который предает, понимая невинность Христа. Ведь Анна тоже предает, хотя сейчас она еще этого до конца не понимает. Но инстинктивно, жалея Пилата, она чувствует нечто близкое, так как, с точки зрения автора, в такой же жалости нуждается она сама. Это отчетливо возникнет в сознании героини не сейчас, в апогей ее преступного счастья с Вронским, а позже, когда придет расплата.

Огромную роль для понимания смысла эпиграфа и удивительных слов Бога «Аз воздам» играет поражающая своим драматизмом сцена свидания с сыном. Миг встречи матери с сыном оказывается чрезвычайно важным в движении смысла эпиграфа. Момент пробуждения ребенка выписан Толстым настолько живописнопластично, что на глазах читателя происходит рождение маленького человека 


\section{8}

в сознании матери. Она как будто заново открывает для себя своего сына.

Эта глубоко драматическая сцена, несмотря на свою психологическую сложность и неоднозначность, - суд над Анной. Здесь все очень значимо: новое рождение сына после долгой разлуки, удивление матери. Новое открытие утраченной способности любить - слезы Анны. А Сережа, «блаженно улыбаясь, бросился к ней, двигался под ее руками, чтобы разными местами тела касаться ее рук». Подробно описывая счастье ребенка, автор заставляет героиню осознать не только свою трагедию, но и предательство любви и веры. Маленький Сережа, подобно Христу, прощает ее:

Я знал... знал, что ты придешь...

Он жалеет мать: «Лучше тебя нет», целует руки матери. Это суд над Анной, но суд в духе Толстого: «...нет правых, нет виновных» и Евангелия: «Не судите, да не судимы будете». И тем не менее всем ходом романа Анна осуждена. Толстой таким образом выстроил композицию романа, что обреченность Анны становится очевидной. Она сама чувствует, что лучшая часть ее души зарастает. И полное душевное опустошение в последней сцене. Нельзя изменить законы человеческого духа, игнорировать их силу. То, что было заявлено в мастерской художника Михайлова, получило полное развитие в романе.

Не останавливаясь подробно на тонкостях перевода Жуковского, чему в нашем издании будут посвящены специальные комментарии ${ }^{26}$, укажем лишь на то, что имеет самое прямое отношение к эстетике центральной для него темы «вочеловечивания Абсолюта в образе Иисуса Христа». Сравнивая его перевод с переводом 
Российского Библейского общества (1819), изданным Н. Гречем, который, конечно, знал Жуковский, и с синодальным переводом, вышедшим уже после Жуковского, следует отметить, что Новый Завет в переводе Жуковского в большей мере сохраняет библейский стиль за счет, главным образом, бережного сохранения поэтического звучания славянизмов и библейских плеоназмов. Приведем примеры:

Блаженны изгнанные за правду, ибо их есть Царство Небесное (Мф. 5:10).

\section{Перевод Жуковского:}

\footnotetext{
${ }^{26}$ При финансовой поддержке РГНФ нами ведется работа над подготовкой к переизданию Нового Завета в переводе В. А. Жуковского.
}

Блаженны гонимые ради правды, ибо их есть Царствие небесное.

Вы - соль земли. Если же соль потеряет силу, то чем сделаешь ее соленою? Она уже ни к чему годна не будет, как разве выбросить ее вон, под ноги людям (Мф. 5:13).

Перевод Жуковского:

Вы - соль земли, когда же соль обуяет ${ }^{27}$, разве на то единое годна, чтобы иссыпали ее вон, на попрание человекам.

И зажегши свечу, не ставят ее под сосудом, но на подсвечнике, и светит всем в доме (Мф. 5:15).

Перевод Жуковского:

И возжегши светильник, не ставят его под сосудом, но на светильнице ${ }^{28}$, и светит всем, кто во храмине.

Здесь всюду мы видим полную ориентацию Жуковского на церковнославянский текст. Это ведет к 
соблюдению высокости евангельской мысли. У Жуковского используются яркие образы и поэтический стиль. Перевод Жуковского передает самую суть высокого Божественного присутствия в слове и в жизни. Выступая на круглом столе по поводу Библии и говоря о том, что синодальный перевод не учитывает пушкинское развитие языка, прежде всего в отношении к славянизмам, С. Аверинцев прямо указывает на это:

Для некоторых мест, где синодальный перевод не дает славянизмов, я предложил бы именно славянизмы ${ }^{29}$.

По мнению исследователя, пушкинское и послепушкинское развитие языка выработало новую чувствительность по отношению к славянизмам. Рекомендации С. Аверинцева переводчикам «больше оглядываться на славянский перевод, чем на синодальный», напрямую соотносятся с переводом Жуковского, поэтически воспринявшего высокие славянизмы Евангелия.

Говоря о традиционных формах священной библейской поэзии в проповеди Иисуса Христа, А. Мень писал:

Нередко слова Его звучали величественным речитативом, напоминая гимны древних пророков ${ }^{30}$.

\footnotetext{
${ }^{27}$ Рядом пояснение Жуковского: «утратит силу».

${ }^{28}$ Было: свешнице.

${ }^{29}$ Аверинцев С. С. [Выступление на круглом столе] // Перевод Библии: Материалы конференции. М. 28-29 ноября 1994 / Институт перевода Библии. М., 1996. С. 39.

${ }^{30}$ Прот. Александр Мень. Сын человеческий. D. L., 1983. С. 79.

160

Этому в переводе Жуковского служила ориентация на церковнославянский текст.

Глубокое исследование Библии и перевод Нового
} 
Завета получили непосредственное отражение в нравственно-философских исканиях, эстетике и художественном творчестве Жуковского. Прежде всего следует указать на такую кардинальную проблему эстетики Жуковского и романтиков вообще, как проблема свободы и необходимости. Наиболее четко и всесторонне она решалась в процессе восприятия Жуковским идей Руссо. Проблема свободы и необходимости занимает центральное место именно в IV книге «Эмиля», в «Исповедании савойского викария» (чтение 1830-х годов). Сейчас эти вопросы связаны непосредственно с религией. К словам Руссо о Божестве, «которое движет Вселенную и дает всему порядок, создает волю и разум, но которое остается непознанным и невидимым», Жуковский приписывает:

Философ видит Бога в создании, но не видит его в нем самом - религия его видит в нем самом и ставит его в отношение с человеком.

Бог в данном случае - духовная сила, которая руководит свободой воли и которую нельзя постичь рассудком, но «что она есть и действует, говорит человеку сердце» ${ }^{31}$. Идея таинственного бытия, невыразимости души человека во многом связана с этими стержневыми мыслями Жуковского.

В религиозно-философских статьях Жуковского 1840$\mathrm{x}$ годов этот тезис получает развитие и обоснование:

Вера есть возвышенный акт человеческой воли, в ней соединяется воедино благодать и человеческая свобода. Вера есть свободное покорение ума и воли откровению... Вера есть свободный акт воли.

Эта мысль постоянно варьируется Жуковским:

Вера в Бога есть действие нашей свободы ${ }^{32}$.

Покорность Богу - это не предание себя во власть 
$\begin{array}{llr}\text { необходимости, } & \text { мертвого } & \text { механического } \\ \text { предопределения, } & \text { уничтожающего } & \text { всякую }\end{array}$

нравственность, всякое достоинство человеческое, это верховная свобода, верховное величие ${ }^{33}$.

${ }^{31}$ Библиотека В. А. Жуковского в Томске. Ч. 3. Томск, 1988. С. 9.

${ }^{32}$ РНБ, ф. 286, оп. 1, № 70а, л. 9, 10, 13.

${ }^{33}$ Там же, л. 8, 13.

Но, утверждая свободу личного выбора, Жуковский связывает еe с нравственным контролем со стороны надличных сил.

В «Записной книжке» (содержащей рассуждения, озаглавленные «О свободе», «О Боге», «О совершенном состоянии России», наброски плана «Агасфера») Жуковский уточняет:

Никакая человеческая воля без содействия воли высшей не может ввести в душу веру, сколько бы душа того не желала ${ }^{34}$.

Иными словами, основой свободы человеческой воли, по Жуковскому, является воля Бога. Свобода воли опасна и слепа, когда она связана только с разумом и когда человек подавляет в себе инстинкт совести, «инстинкт, который вложен Богом и контролируется Богом» ${ }^{35}$.

Утверждая подлинную свободу, основанную на вере, Жуковский был во многом близок к декабристам 18301840-х годов. Батеньков, также много рассуждавший о свободе и необходимости, приходит к религиозному пониманию свободы.

Свободный человек - это человек поверивший ${ }^{36}$.

Исследование Библии, подготовка к переводу Нового Завета оказали решительное воздействие на позднюю эстетику Жуковского. Так же, как декабристы Кюхельбекер, Лунин, Батеньков, А. Бестужев, Жуковский 
связывал с христианской религией принципиально новый этап в развитии искусства слова.

Христианство своим явлением... разоблачило перед человеком его высокую природу и возвеличило человеческую душу, указав ей ее падение и вместе с ним ее права на утраченное совершенство и блаженство, возвращенные ей искуплением ${ }^{37}$.

Важнейшая для Жуковского идея жизнестроительства углубляется, уточняется на основе философии откровения, почерпнутой из Нового Завета. Обо всем этом мы говорили специально, анализируя такие поздние статьи Жуковского, как «О меланхолии в жизни и в поэзии», «О поэте и современном его значении», «Две сцены из "Фауста"».

\footnotetext{
${ }^{34}$ Там же, № 60, л. 2.

35 Там же, л. 2.

${ }^{36}$ РГБ, ф. 20, карт. 6, ед. хр. 8, л. 5.

37 Жуковский В. А. Эстетика и критика. М., 1985. С. 345.
}

\section{2}

Самое главное назначение поэзии - «являть святость жизни». Созидательная концепция искусства первоисточник художественного творчества. В письме к Жуковскому от 29 декабря 1847 года Гоголь еще и еще раз подчеркивает эти важнейшие для него мысли:

Искусство не разрушение... Искусство вносит стройность в порядок в обществе. Так же, как религия, искусство помогает жить на Земле.

Это очень импонировало Жуковскому:

Так прекрасно и справедливо сказал ты в письме своем, назвав искусство «примирением с жизнью».

Жуковский в поздний период своего творчества непримирим к тем романтикам, которые вместо идей 
созидания несут скепсис и разрушение. С особой силой сейчас Жуковский не приемлет байронизм во всех его ответвлениях «вулканической разрушительности в корифеях и мелкого обличительства в эпигонах».

Важнейшей в статье «О поэте и современном его значении» является проблема слова как универсальная проблема творчества. «Поэт, - читаем мы в названной статье, - творит словом и это творческое слово... Это есть тайное, всеобъемлющее глубокое действие откровенной красоты» ${ }^{38}$. Сакральностью поэтического слова Жуковский объясняет иррациональность его воздействия на читателя.

Мы можем дать себе отчет в том, что нас увлекает... но то, что безотчетно и неуловимо и что, однако, всему этому дает жизнь, это дух поэта, в создании его тайно соприсутственный!

Поэтическое слово в понимании Жуковского отрывок «чего-то целого недостижимого», Слова Божия, Логоса, который великий поэт пытается выразить неповторимой «музыкой слова» ${ }^{39}$.

Чтобы в полной мере понять трактовку Жуковским глубинного смысла евангельского слова, необходимо присмотреться к его переводу Евангелия от Иоанна. Здесь c большой полнотой выражено отношение поэта к важнейшему для него понятию Слова - Логосу. С. С. Аверинцев проницательно заметил, что Евангелие от Иоанна, начинающееся стихом «В начале было Слово», является как будто бы аналогом повествованию Ветхого Завета о сотворении мира («В начале сотворил Бог небо и землю»). Этим подчеркивается

\footnotetext{
${ }^{38}$ Там же. С. 333.

${ }^{39}$ Там же. С. 334.
}

универсальная, созидательная, сакральная сущность 
Слова - основного орудия преображения человеком себя, своего внутреннего мира. Характерно, что в архиве поэта первые дошедшие до нас подготовительные материалы к переводу Священного Писания открываются разделом «О слове жизни» ${ }^{40}$.

Говоря о своеобразии перевода Жуковским ст. 1 Евангелия от Иоанна, свящ. Д. Долгушин сравнивает его с переводом К. Победоносцева и РБО (митрополит Филарет) и утверждает, что перевод Жуковского («в Боге») не имеет основания ни в славянском, ни в греческом, ни во французском (де Сасси), ни в немецком (Лютер) текстах. Исследователь прав, отмечая, что, вероятно, здесь перед нами попытка самостоятельной интерпретации. Но, будучи на страже «строгой теологии», он предполагает, что Жуковский, скорее всего, должен был вернуться к этому переводу и доработать его.

Нам представляется, что самостоятельная интерпретация Жуковским трактовки евангельского слова принципиальна, хотя сам поэт представлял неточность своего перевода с точки зрения догматов теологии:

Я невежа в теологии, думаю, что можно быть православным христианином и без обширной теологической учености ${ }^{41}$.

Но, обращаясь к А.С. Стурдзе как к опытному путеводителю, Жуковский, думается, в ряде своих отступлений от канона был принципиален. В письме П. А. Плетневу от 6 марта 1850 года он сам объяснил смысл своего труда по переводу Нового Завета стремлением «погрузиться» в Библию, вчитаться в нее, «занять себя главным предметом жизни» ${ }^{42}$.

Проблема Слова, которой посвящен ст. 1 Евангелия от Иоанна, и была для поэта «главным предметом жизни». Не случайно Жуковский делает, как мы видели, этот стих предметом специального обсуждения в одной из своих программных 


\footnotetext{
${ }^{40}$ Д. В. Долгушин сравнивает первые 7 ст. Евангелия от Иоанна в переводе Жуковского с переводом РБО в своей статье «Новый Завет в переводе Жуковского» (в печати). Приведем это сравнение: Жуковский: «В начале было Слово и Слово было в Боге, и Бог был Слово». РБО: «В начале было Слово, и Слово было у Бога, и Бог было Слово». Победоносцев: «В начале было Слово, и Слово было к Богу, и Слово было Бог». C. 18 .

${ }^{41}$ Переписка В. А. Жуковского с А. С. Стурдзою. Одесса, 1855.

${ }^{42}$ Сочинения и переписка П. А. Плетнева. Т. 3. СПб., 1885. С. 649.
}

статей «Две сцены из "Фауста"». Здесь он так толкует этот стих:

Слово Божие, напротив, есть Бог - и Бог как творец, и Бог как творение, от века бывшее в Боге и с Богом, из воли его истекшее и в нем заключенное, но с ним не слиянное и с ним не тождественное, имевшее начало, ибо оно творение, и безначальное, ибо оно есть непосредственное Божие творение, а Бог действует в вечности, в которой было, есть и будетодно и то же ${ }^{43}$.

Здесь, действительно, заключена суть концепции слова Жуковского, и особенность его перевода принципиально выражает эту суть, так как, говоря о двойственной универсально-символической роли евангельского Слова и настойчиво отстаивая его Божественную сущность, поэт раскрывает самую суть его поэтики «невыразимого».

Слово (в смысле Иоанна) принадлежит только Богу, человеку оно недоступно. Он только имеет слова, которые суть не иное что, как атомы всеобъемлющего Божия слова. Из сего следует, что слово Божие - сам Бог и его истина - не может быть выражено словами человеческими... все наши слова... суть только отрывки чего-то целого... сколько бы ни была велика их цепь, все она будет один отрывок... если первое звено ее не прикрепится к вечному, все выражающему слову, к 
Богу ${ }^{44}$.

Bсе это имеет прямое отношение к эстетике «невыразимого», которая сейчас значительно уточняется в сознании Жуковского и обретает сакральный евангельский смысл.

Наконец, говоря об эстетике перевода Жуковским Нового Завета, необходимо сделать акцент на жанровой природе творчества великого поэта. Библия и, в частности, Новый Завет - энциклопедии всевозможных жанров, оказавших значительное влияние на жанровую картину творческого наследия Жуковского. Чтение Нового Завета, пометы, сам перевод и творчество свидетельствуют о преимущественном интересе поэта к таким жанрам, как притча, исповедь, псалом.

Особенно глубоко интересовался Жуковский притчей как важнейшим жанром Священного Писания. Доходчивость и популярность притчи объяснялась тем, что она, как правило, основывалась на событиях реальной жизни. Об этом говорит А. Мень:

\footnotetext{
${ }^{43}$ Жуковский В. А. Эстетика и критика. С. $351-352$.

${ }^{44}$ Там же. С. 352.
}

Особенно любил Иисус примеры из повседневной жизни притчи. В них наиболее полно запечатлелось его учение ${ }^{45}$.

Жуковский уже в подготовительных бумагах к переводу, озаглавливая содержание частей Нового Завета, называет все важнейшие притчи Евангелия (Мф. Притча о сеятеле. С. 14-20; Изъяснение притчи. С. 21-25; Притча о светильнике. С. 26-29; Лк. Притча о семени, брошенном в землю. С. $1-9$; Притча о смоковнице. C. 11-32 и т. д.). При этом Жуковский прекрасно понимал, что евангельские притчи относятся к 
«первоосновам человеческого существования» (С. Аверинцев). Пришедшая из христианского Писания, притча была направлена к сути нравственного выбора человека. Многие произведения Жуковского представляют собою глубокое взаимопроникновение, синтез притчи и исповеди. Вершиной этого являются произведения 1830-1840-х годов («Ундина», «Агасфер»).

Наиболее полным художественным воплощением евангельской темы является последнее произведение Жуковского, его «лебединая песнь», поэма «Странствующий жид», о которой мне приходилось говорить неоднократно. Сегодня сделаем только важные для нашей темы добавления.

Итогом нравственно-психологической эволюции Агасфера является его убеждение в необходимости нести людям правду о Христе.

Внутренний конфликт произведения создается не только за счет антиномичности самого образа Агасфера, но и в связи с его эволюцией, «движением души». Если такие проблемы, как жизнь и смерть, подлинное и мнимое бессмертие, свобода и необходимость, в какой-то мере можно отнести и к герою легенды как таковой, то проблемы слова, двух типов романтической личности, тема «искусство и религия» (покаяние и искупление через деятельную скорбь и очистительное страдание) имеют корни в поздней эстетике Жуковского. Воплощение в поэме этих идей оживило сюжет о Вечном жиде, придало ему не только современное звучание, но и вневременность, универсальность. Это проявилось и в организации хронотопа поэмы.

Циклическая смена эпох, представленная в поэме, имела для автора весьма актуальный смысл. Иоанн пишет Откровение, почувствовав угрозу христианству. Жуковский, в свою очередь, ощутив кризис современной 
ему жизни, видит спасение в религии, в вере как важнейшем источнике

${ }^{45}$ Прот. А. Мень. Сын человеческий. С. 79. 